\title{
Comparison of Vitek and Cobas Micro systems with a semiautomated conventional microsystem for identification and susceptibility testing of Gram negative bacilli
}

\author{
A M Simoons-Smit, D M Maclaren
}

\begin{abstract}
Aims-To compare the sensitivity and specificity of two semiautomated systems against a conventional (MIC 2000) test system for the identification and antibiotic susceptibility of Gram negative bacteria.

Methods-Clinical isolates of Gram negative bacilli (188 urinary and 229 nonurinary strains) were identified and tested for antibiotic susceptibility in the Cobas Micro and MIC 2000 systems. Of these, 359 strains were then tested in the Vitek and MIC 2000 systems. Two hundred and forty three strains were tested in all three systems immediately after isolation. Forty three were also tested only in the Vitek and MIC 2000 systems immediately after isolation. The remaining 174 strains were tested after storage
\end{abstract} at $-20^{\circ} \mathrm{C}$ for several months.

Results-The Cobas Micro and MIC 2000 systems agreed on the identification of 310 of the $417(74 \cdot 3 \%)$ strains; the Vitek and MIC 2000 systems agreed on 338 of the $359(94 \cdot 2 \%)$ strains. The Cobas Micro system correctly identified $86.8 \%$ of strains tested after storage and $65.4 \%$ of those immediately after isolation. Organism-antibiotic combinations (nonurinary isolates) were tested in the Cobas Micro and MIC 2000 systems $(n=2335)$, in the Vitek and MIC 2000 systems (n = 999). Essential correlation (complete agreement plus minor errors) was observed in $98 \%$ (with $90 \%$ complete agreement) in the former and in $97 \%$ (with $86 \%$ complete agreement) in the latter. For the urinary isolates, 1949 organism-antibiotic combinations were analysed in the Cobas Micro and MIC 2000 systems where complete agreement was observed in $92 \%$ (with $3 \%$ very major discrepancies), for 1382 urinary organism-antibiotic combinations tested in the Vitek and MIC 2000 systems, the figures were $95 \%$ and $2 \%$, respectively.

Conclusions-The Vitek system is highly accurate in the identification and antibiotic susceptibility testing of Gram negative bacteria. The Cobas Micro system has many shortcomings in its identification of Gram negative rods, especially freshly isolated strains, but it is comparable with the Vitek system in antibiotic susceptibility testing.

(F Clin Pathol 1994;47:71-75)
Reliable identification and susceptibility testing of bacteria are important for the diagnosis and treatment of infectious diseases. During the past decade, great progress has been made in the automation of microbiological techniques. Several systems with a varying degree of automation are now available for use in routine diagnostic laboratories. The choice of one system over another depends on several factors, including time required for determination and sensitivity testing, spectrum of organisms covered, mode of performance, personal preferences, and costs.

Several comparison studies of instruments for identification and susceptibility testing have been reported. Most systems have an efficiency of more than $90 \%$ and reproducibilities ranging from $85-96 \% .^{1-8}$ Stager and Davis $^{9}$ have comprehensively reviewed the available systems.

\section{Methods}

A total of 417 routine clinical isolates of Gram negative bacteria (188 urinary strains, 180 non-urinary, and 49 non-urinary Pseudomonas strains) were tested in this study. Of these, 243 strains were collected and tested (on the day of the first isolation) in the two commercial test systems (Vitek and Cobas Micro) and the conventional test system (MIC 2000), and 43 strains were tested in only two systems (Vitek and MIC 2000). The remaining strains $(n=174)$ were kept frozen at $-20^{\circ} \mathrm{C}$ until use. These strains had been tested before, but not simultaneously, in the two commercial systems and compared with the conventional system.

CONVENTIONAL TEST SYSTEM

Biochemical identification and microdilution minimum inhibitory concentration (MIC) testing were done in microtitre trays prepared inhouse using an MIC 2000 dispenser (Dynatech, The Netherlands), dispensing $0.1 \mathrm{ml}$ volumes of each biochemical substrate and antimicrobial agent dilution per well. Identification was made on the basis of 22 biochemical reactions. If a definitive identification was not obtained, or if there was a disagreement in identification we used the API 20E (API bioMèrieux Benelux BV, The Netherlands) for confirmation. Pseudomonas sp were identified by their pigment production and growth at $42^{\circ} \mathrm{C}$ or by the API NE (API bioMèrieux).

Six appropriate twofold diluted concentrations of 12 different antimicrobial agents in 
Isosensitest broth (Unipath) were used to determine the MICs. Trays were inoculated with a bacterial suspension $\left(5 \times 10^{5} \mathrm{cfu} / \mathrm{ml}\right)$ of fresh colonies in distilled water using an MIC 2000 inoculator (Dynatech). The trays were incubated at $37^{\circ} \mathrm{C}$ for 18 hours, after which the MIC endpoint was read visually as the lowest concentration of antimicrobial agent that completely inhibited bacterial growth. The reference strains of Escherichia coli (ATCC 25922) and Pseudomonas aeruginosa (ATCC 27853) served as controls. Susceptibility was determined as $\mathrm{S}$ (sensitive), I(intermediate) for non-urinary strains, or $\mathbf{R}$ (resistant), according to the breakpoints of

Table 1 Comparison of identification of Gram negative micro-organisms by MIC 2000, Cobas Micro, and Vitek

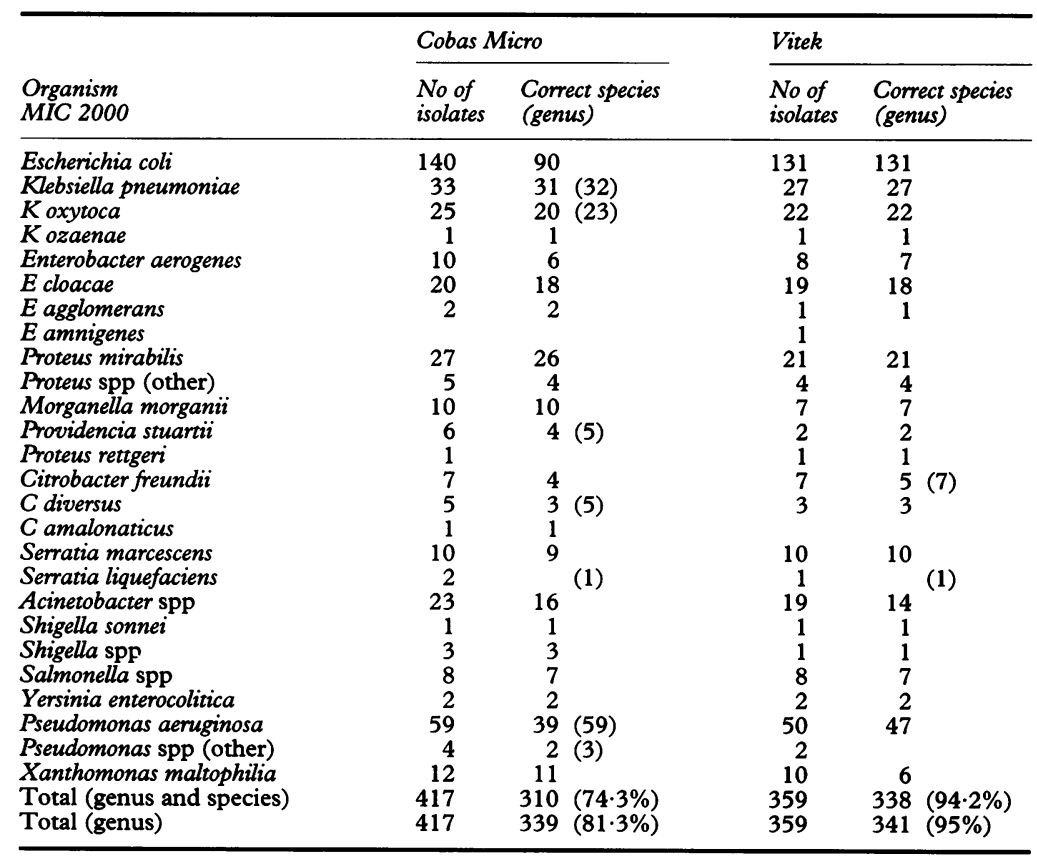

Table 2 Comparison of identification of Gram negative micro-organisms by Cobas Micro immediately after isolation or after storage at $-20^{\circ} \mathrm{C}$

\begin{tabular}{|c|c|c|c|c|}
\hline \multirow[b]{2}{*}{$\begin{array}{l}\text { Organism } \\
\text { MIC } 2000\end{array}$} & \multicolumn{2}{|c|}{ Cobas Micro at isolation } & \multicolumn{2}{|c|}{$\begin{array}{l}\text { Cobas Micro } \\
\text { after storage }-20^{\circ} \mathrm{C}\end{array}$} \\
\hline & $\begin{array}{l}\text { No of } \\
\text { isolates }\end{array}$ & $\begin{array}{l}\text { Correct species } \\
\text { (genus) }\end{array}$ & $\begin{array}{l}\text { No of } \\
\text { isolates }\end{array}$ & $\begin{array}{l}\text { Correct species } \\
\text { (genus) }\end{array}$ \\
\hline Escherichia coli & 108 & 63 & 32 & 27 \\
\hline Klebsiella pneumoniae & 16 & $14(15)$ & 17 & 17 \\
\hline $\begin{array}{l}\text { Koxytoca } \\
\text { Kozaenae }\end{array}$ & 14 & $9(12)$ & 11 & 11 \\
\hline $\begin{array}{l}\text { Kozaenae } \\
\text { Enterobacter aerogenes }\end{array}$ & 7 & 4 & $\begin{array}{l}1 \\
3\end{array}$ & $\begin{array}{l}1 \\
2\end{array}$ \\
\hline E cloacae & 16 & 14 & 4 & 4 \\
\hline E agglomerans & 1 & 18 & 2 & 2 \\
\hline Proteus mirabilis & 16 & 15 & 11 & 11 \\
\hline Proteus spp (other) .. & 1 & 1 & 4 & 3 \\
\hline Morganella morganii & 3 & 3 & 7 & 7 \\
\hline $\begin{array}{l}\text { Providencia stuartii } \\
\text { Proteus rettgeri }\end{array}$ & & & 6 & $4(5)$ \\
\hline $\begin{array}{l}\text { Proteus rettgeri } \\
\text { Citrobacter freundii }\end{array}$ & & & 1 & \\
\hline Citrobacter freundii & 4 & 3 & 3 & 1 \\
\hline$C$ diversus & 3 & $1(3)$ & 2 & 2 \\
\hline $\begin{array}{l}\text { Camalonaticus } \\
\text { Serratia marcescens }\end{array}$ & & & 1 & 1 \\
\hline $\begin{array}{l}\text { Serratia marcescens } \\
\text { S liquefaciens }\end{array}$ & 4 & 4 & 6 & 5 \\
\hline $\begin{array}{l}\text { S liquefaciens } \\
\text { Acinetobacter spp }\end{array}$ & 1 & (1) & 1 & \\
\hline $\begin{array}{l}\text { Acinetobacter spp } \\
\text { Shigella sonnei }\end{array}$ & 13 & 7 & 10 & 9 \\
\hline $\begin{array}{l}\text { Shigella sonnei } \\
\text { Shigella spp }\end{array}$ & 1 & 1 & 3 & 3 \\
\hline $\begin{array}{l}\text { Salmonella spp } \\
\text { Yersinia enterocolitica }\end{array}$ & 1 & 1 & $\begin{array}{l}7 \\
2\end{array}$ & $\begin{array}{l}6 \\
2\end{array}$ \\
\hline Pseudomonas aeruginosa & 30 & $15(30)$ & 29 & $24(29)$ \\
\hline Pseudomonas spp (other) & 1 & & 3 & $2(3)$ \\
\hline Xanthomonas maltophilia & 4 & 4 & 8 & 7 \\
\hline Total (genus and species) & 243 & $159(65.4 \%)$ & 174 & $151(86.8 \%)$ \\
\hline Total (genus) & 243 & $181(74 \cdot 5 \%)$ & 174 & $158(91 \%)$ \\
\hline
\end{tabular}

the WRG (Werkgroep Richtlijnen Gevoeligheids-bepalingen, The Netherlands). The MIC 2000 was supplemented with the disc diffusion test for those antibiotics which were present in one or both of the commercial systems, but not in the MIC 2000 system.

\section{VITEK SYSTEM}

The Vitek system (bioMèrieux) is an integrated modular system consisting of a filling sealer unit, reading incubator, computer control module, data terminal, and multicopy printer. The Gram negative identification card was used for the identification of all strains. The Gram negative susceptibility-EU card and Gram negative susceptibility-HS cards (Pseudomonas strains) were used for the susceptibility testing of the 243 strains which were simultaneously tested in the Cobas Micro and the MIC 2000 systems, and the Gram negative susceptibility-GD, Gram negative susceptibility-OP, or Gram negative susceptibility-UA cards (urinary strains) for the susceptibility testing of the remaining strains. Cards were inoculated with a standardised inoculum and tests were done according to the manufacturer's instructions. Identification and MIC results were automatically printed at the end of the incubation period, which was six to 10 hours for most isolates. The WRG breakpoints were used for the interpretation of the MIC results.

Software, version R 6.4 (Vitek), was used.

\section{COBAS MICRO SYSTEM}

The Cobas Micro System (Becton Dickinson, The Netherlands) is a computer controlled instrument for automatic analysis and the interpretation of identification and susceptibility testing using specifically designed rotors. The system consists of a rotor centrifuge station, thermal printer, screen, keyboard, bar code reader and filter photometer. After centrifugation in the rotor centrifugation station, which permits the distribution of the inoculum into the rotor chambers, the rotor is incubated overnight at $37^{\circ} \mathrm{C}$. After incubation the filter photometer measures absorbance values in the individual rotor chambers. Two types of rotor were used: a 33 chamber rotor for identification and a 16 chamber rotor for antimicrobial susceptibility testing. Rotors were inoculated with a standardised inoculum (Inocheck, Becton Dickinson, The Netherlands) and tests were done according to the manufacturer's instructions. The built-in computer provided an automated interpretation of the results.

\section{CLASSIFICATION OF RESULTS OF}

SUSCEPTIBILITY TESTING

The comparative results were classified as follows:

(1) Complete agreement: the results were within the same category (sensitive, intermediate (for non-urinary strains), or resistant).

(2) Minor error (for non-urinary strains only): the results were within a category which was sensitive or resistant for one system and intermediate for the other system. 
(3) Major error: the results in the test system were in the resistant category whereas they were sensitive in the standard system.

(4) Very major error: the results in the test system were in the sensitive category, whereas they were resistant in the standard system.

(5) Essential correlation: this comprised the sum of the percentages of complete agreement and minor error.

\section{Results}

IDENTIFICATION

Table 1 compares the identification of the Gram negative isolates using the MIC 2000, Cobas Micro, and Vitek systems, respectively. No additional "external" reactions were used in the identification of the strains in the different systems. Of the 359 strains tested in complete agreement with the MIC 2000

Table 3 Discrepancies in identification using MIC 2000, Cobas Micro, and Vitek

\begin{tabular}{|c|c|c|c|c|c|c|}
\hline MIC 2000 & $\begin{array}{l}\text { Total } \\
\text { No of } \\
\text { strains }\end{array}$ & $\begin{array}{l}\text { Cobas Micro } \\
\text { misidentification }\end{array}$ & $\begin{array}{l}\text { No of } \\
\text { strains }\end{array}$ & $\begin{array}{l}\text { Total } \\
\text { No of } \\
\text { strains }\end{array}$ & Vitek misidentification & $\begin{array}{l}\text { No of } \\
\text { strains }\end{array}$ \\
\hline Escherichia coli & 140 & $\begin{array}{l}\text { Shigella sonnei } \\
\text { Shigella spp } \\
\text { Vibrio spp } \\
\text { Plesiomonas }\end{array}$ & $\begin{array}{r}32 \\
10 \\
7 \\
1\end{array}$ & & & \\
\hline Klebsiella pneumoniae & 33 & $\begin{array}{l}\text { Serratia plymuthica } \\
\text { Kozaenae }\end{array}$ & 1 & & & \\
\hline Koxytoca & 25 & $\begin{array}{l}\text { Vibrio parahemolyticus } \\
\text { K pneumoniae } \\
\text { E cloacae }\end{array}$ & $\begin{array}{l}1 \\
3 \\
1\end{array}$ & & & \\
\hline Enterobacter aerogenes & 10 & $\begin{array}{l}\text { Kluyvera ascorbata } \\
\text { Klebsiella spp } \\
\text { Shigella fonticola }\end{array}$ & $\begin{array}{l}2 \\
1 \\
1\end{array}$ & 8 & Kpneumoniae & 1 \\
\hline $\begin{array}{l}E \text { cloacae } \\
\text { E amnigenes }\end{array}$ & 20 & C freundii & 2 & $\begin{array}{r}19 \\
1\end{array}$ & $\begin{array}{l}\text { Serratia fonticola } \\
\text { C freundii/amalonaticus }\end{array}$ & $\begin{array}{l}1 \\
1\end{array}$ \\
\hline $\begin{array}{l}\text { P mirabilis } \\
P \text { vulgaris } \\
\text { Providencia stuartii }\end{array}$ & $\begin{array}{r}27 \\
3 \\
6\end{array}$ & $\begin{array}{l}\text { Flavobacterium } \\
\text { Proteus rettgeri } \\
\text { Morganella morganii } \\
\text { P rettgeri }\end{array}$ & $\begin{array}{l}1 \\
1 \\
1 \\
1\end{array}$ & & & \\
\hline $\begin{array}{l}\text { Proteus rettgeri } \\
\text { C freundii }\end{array}$ & $\begin{array}{l}1 \\
7\end{array}$ & $\begin{array}{l}\text { Fodoratum } \\
\text { Yersinia enterocolitica } \\
\text { Chryseomonas luteola } \\
\text { Y pseudotuberculosis }\end{array}$ & $\begin{array}{l}1 \\
1 \\
1 \\
1\end{array}$ & 7 & $C$ amalonaticus & 2 \\
\hline $\begin{array}{l}\text { C diversus } \\
\text { Serratia marcescens }\end{array}$ & $\begin{array}{r}5 \\
10\end{array}$ & $\begin{array}{l}\text { C amalonaticus } \\
\text { K pneumoniae }\end{array}$ & $\begin{array}{l}2 \\
1\end{array}$ & & & \\
\hline S liquefaciens & 2 & $\begin{array}{l}S \text { marcescens } \\
\text { E cloacae }\end{array}$ & $\begin{array}{l}1 \\
1\end{array}$ & 1 & $S$ marcescens & 1 \\
\hline Acinetobacter & 23 & $\begin{array}{l}\text { Moraxella spp } \\
\text { P rettgeri } \\
\text { Pasteurella aerogenes } \\
\text { Alcaligenes }\end{array}$ & $\begin{array}{l}3 \\
1 \\
1 \\
2\end{array}$ & 19 & $\begin{array}{l}\text { Non-viable organism } \\
\text { No growth } \\
\text { Unidentified organism }\end{array}$ & $\begin{array}{l}3 \\
1 \\
1\end{array}$ \\
\hline $\begin{array}{l}\text { Salmonella spp } \\
\text { Ps aeruginosa }\end{array}$ & $\begin{array}{r}8 \\
59\end{array}$ & $\begin{array}{l}\text { Hafnia alvei } \\
\text { P putida } \\
\text { P fluorescens } \\
\text { P mendocina } \\
\text { P stutzeri }\end{array}$ & $\begin{array}{l}1 \\
7 \\
7 \\
5 \\
1\end{array}$ & $\begin{array}{r}8 \\
50\end{array}$ & $\begin{array}{l}\text { Unidentified organism } \\
\text { Unidentified organism }\end{array}$ & $\begin{array}{l}1 \\
3\end{array}$ \\
\hline $\begin{array}{l}\text { Ps aeruginosa } \\
\text { Ps fluorescens } \\
\text { Ps stutzeri }\end{array}$ & $\begin{array}{l}1 \\
1\end{array}$ & $\begin{array}{l}\text { Alcaligenes } \\
P \text { alcaligenes }\end{array}$ & $\begin{array}{l}1 \\
1\end{array}$ & $7^{\star}$ & $\begin{array}{l}\text { Unidentified organism } \\
\text { Flavimonas }\end{array}$ & $\begin{array}{l}1 \\
1\end{array}$ \\
\hline $\begin{array}{l}\text { Ps acidovorans } \\
\text { Xanthomonas maltophilia }\end{array}$ & 12 & Kozaenae & 1 & $\begin{array}{r}1 \\
10\end{array}$ & $\begin{array}{l}\text { Unidentified organism } \\
\text { Unidentified organism }\end{array}$ & $\begin{array}{l}1 \\
4\end{array}$ \\
\hline
\end{tabular}

*Additional strains tested by Vitek and MIC 2000 only.

Table 4 Correlation and classification of results of susceptbility testing for non-urinary Gram negative isolates comparing MIC 2000 with Vitek and Cobas Micro

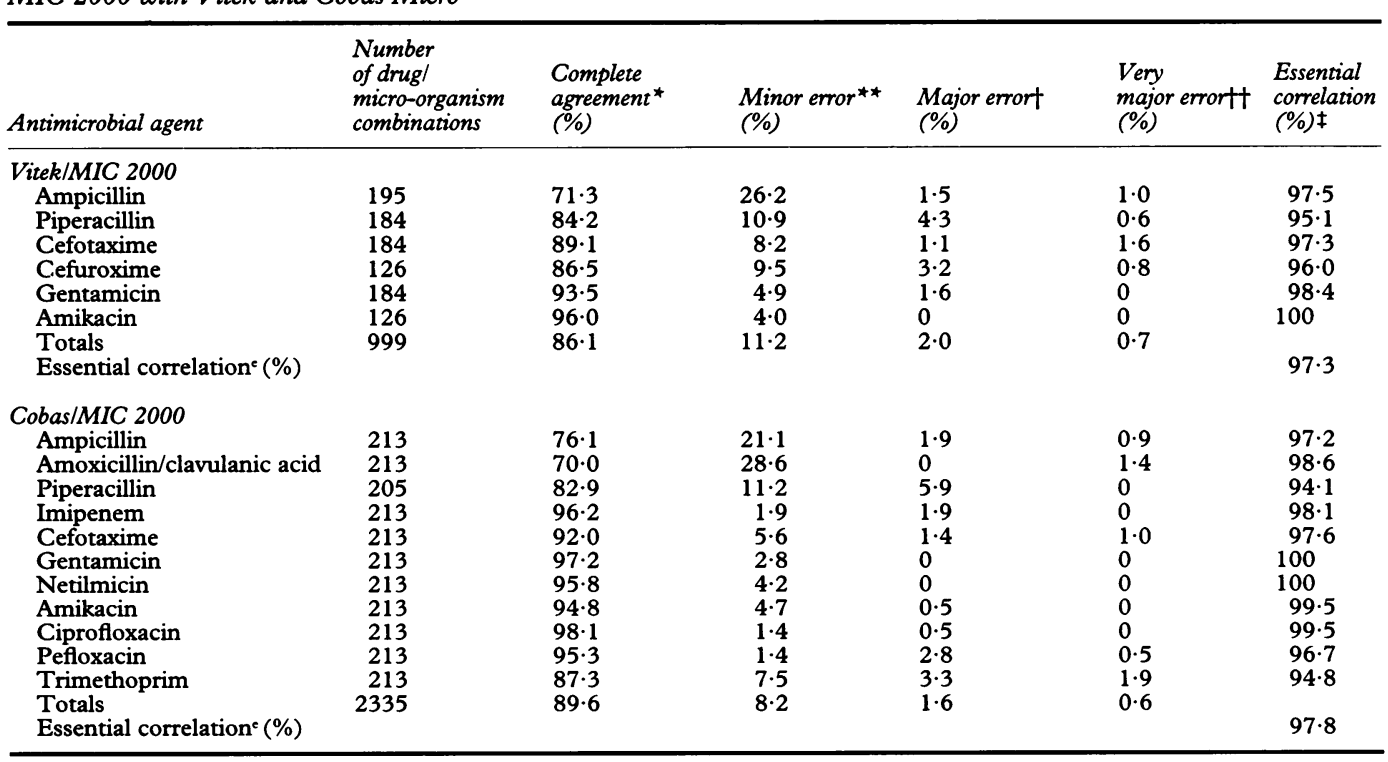

${ }^{\star}$ Category results identical.

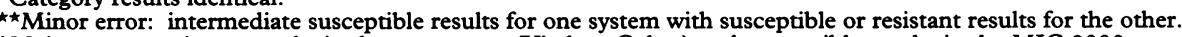

†Major error: resistant results in the test system (Vitek or Cobas) and susceptible results in the MIC 2000.

\#Very major error: susceptible results in the test system (Vitek or Cobas) and resistant results in the MIC 2000.

fec $($ essential correlation $)=$ complete agreement plus minor error 
Table 5 Correlation and classification of results of susceptibility testing for urinary Gram negative isolates comparing MIC 2000 with Vitek and Cobas Micro

\begin{tabular}{|c|c|c|c|c|}
\hline Antimicrobial agent & $\begin{array}{l}\text { Number of } \\
\text { drug/ } \\
\text { micro-organism } \\
\text { combinations }\end{array}$ & $\begin{array}{l}\text { Complete } \\
\text { agreement * } \\
(\%)\end{array}$ & $\begin{array}{l}\text { Major } \\
\text { error } \\
(\%)\end{array}$ & $\begin{array}{l}\text { Very } \\
\text { major } \\
\text { error* } \\
(\%)\end{array}$ \\
\hline \multicolumn{5}{|l|}{ Vitek/MIC 2000} \\
\hline Ampicillin & 157 & $94 \cdot 3$ & $4 \cdot 5$ & $1 \cdot 2$ \\
\hline Amoxicillin/clavulanic acid & 119 & 89.9 & $8 \cdot 4$ & 1.7 \\
\hline Piperacillin & 119 & 93.3 & 5.9 & 0.8 \\
\hline Norfloxacin & 156 & $\mathbf{9 8 \cdot 7}$ & $1 \cdot 3$ & 0 \\
\hline Nitrofurantoin & 158 & $88 \cdot 6$ & $5 \cdot 1$ & $6 \cdot 3$ \\
\hline Cotrimoxazole & 158 & $93 \cdot 0$ & $5 \cdot 1$ & 1.9 \\
\hline Nalidixic acid & 119 & $96 \cdot 7$ & 0.8 & $2 \cdot 5$ \\
\hline Cefotaxime & 119 & $97 \cdot 5$ & $0 \cdot 8$ & $1 \cdot 7$ \\
\hline Cefuroxime & 119 & $98 \cdot 3$ & 0 & $1 \cdot 7$ \\
\hline Gentamicin & 158 & $98 \cdot 1$ & 1.9 & 0 \\
\hline Totals & 1382 & $94 \cdot 8$ & $3 \cdot 4$ & $1 \cdot 8$ \\
\hline \multicolumn{5}{|l|}{ Cobas/MIC 2000} \\
\hline Ampicillin & 182 & $88 \cdot 5$ & $6 \cdot 0$ & $5 \cdot 5$ \\
\hline Amoxicillin/clavulanic acid & 182 & $90 \cdot 1$ & $7 \cdot 1$ & $2 \cdot 8$ \\
\hline Piperacillin & $208 t$ & $85 \cdot 1$ & $14 \cdot 4$ & 0.5 \\
\hline Gentamicin & $207 \dagger$ & $97 \cdot 1$ & $2 \cdot 9$ & 0 \\
\hline Pipemidic acid & $208 t$ & $95 \cdot 7$ & $2 \cdot 4$ & 1.9 \\
\hline Norfloxacin & $208+$ & $98 \cdot 1$ & $1 \cdot 4$ & 0.5 \\
\hline Ciprofloxacin & $208 t$ & $98 \cdot 6$ & $1 \cdot 4$ & 0 \\
\hline Sulfamethoxazole & 182 & $91 \cdot 8$ & 0.5 & $7 \cdot 7$ \\
\hline Trimethoprim & 182 & $84 \cdot 6$ & $13 \cdot 7$ & $1 \cdot 7$ \\
\hline Nitrofurantoin & 182 & $85 \cdot 1$ & $2 \cdot 7$ & $12 \cdot 2$ \\
\hline Totals & 1949 & 91.7 & $5 \cdot 2$ & 3.1 \\
\hline
\end{tabular}

* See legend to table 4

†Including Pseudomonas isolates.
Most of the misidentifications with Vitek were with Acinetobacter sp, Pseudomonas sp, or $X$ maltophilia strains (15 strains), which were recorded as unidentified or non-viable microorganisms. Only seven strains in the entire study were misidentified by the Vitek system (table 3). The Cobas Micro system misidentified 107 strains at genus or species level in almost all genera tested (table 3).

\section{ANTIMICROBIAL SUSCEPTIBILITY}

Tables 4, 5, and 6 compare the Vitek and Cobas Micro systems with the MIC 2000 system for the antimicrobial susceptibility testing of non-urinary Gram negative isolates (without Pseudomonas), urinary Gram negative isolates, and non-urinary Pseudomonas isolates, respectively. Complete agreement between the Vitek and MIC 2000 systems for non-urinary strains was obtained in $86.1 \%$ of cases (table 4). Very major errors were obtained in only $0.7 \%$. Between the Cobas Micro and MIC 2000 systems, complete agreement for non-urinary strains was obtained in $89.6 \%$; very major errors occurred in $0.6 \%$. Many minor errors were seen in the Cobas Micro and Vitek systems: $26 \%$ and $21 \%$, respectively, for ampicillin and $28 \%$ for amoxicillin/clavulanic acid in the Cobas system. For the urinary strains (table 5), the figures for complete agreement and for very major errors between the Vitek and MIC 2000 systems were $94.8 \%$ and $1.8 \%$, respectively, and for Cobas Micro and MIC $200091.7 \%$ and $3 \cdot 1 \%$, respectively. Nitrofurantoin yielded the highest number of major errors in both systems, and sulfamethoxazole and ampicillin in the Cobas Micro. For non-urinary Pseudomonas sp, the Vitek system completely agreed with the MIC 2000 system in $75.8 \%$ of results $(0.4 \%$ very major errors). The percentage agreement between Cobas Micro and MIC 2000 was $79.3 \%(0.5 \%$ very major errors) (table 6).

Essential correlation was obtained in more than $95 \%$ of all comparative results except for piperacillin and trimethoprim in the Cobas Micro system.

Table 6 Correlation and classification of results of susceptibility testing for non-urinary Pseudomonas isolates comparing MIC 2000 with Vitek and Cobas Micro

\begin{tabular}{|c|c|c|c|c|c|c|}
\hline Antimicrobial agent & $\begin{array}{l}\text { Number } \\
\text { of drugl } \\
\text { micro-organism } \\
\text { combinations }\end{array}$ & $\begin{array}{l}\text { Complete } \\
\text { agreement * } \\
(\%)\end{array}$ & $\begin{array}{l}\text { Minor error } \\
(\%)\end{array}$ & $\begin{array}{l}\text { Major error } \\
\text { (\%) }\end{array}$ & $\begin{array}{l}\text { Very } \\
\text { major error } \\
(\%)\end{array}$ & $\begin{array}{l}\text { Essential } \\
\text { correlation } \\
(\%)^{\star}\end{array}$ \\
\hline \multicolumn{7}{|l|}{ Vitek/MIC 2000} \\
\hline Piperacillin & 41 & $92 \cdot 7$ & $7 \cdot 3$ & 0 & 0 & 100 \\
\hline Ticarcillin/clavulanic acid & 34 & $50 \cdot 0$ & $44 \cdot 2$ & $2 \cdot 9$ & $2 \cdot 9$ & $94 \cdot 2$ \\
\hline Cefotaxime & 41 & $68 \cdot 3$ & $26 \cdot 8$ & $4 \cdot 9$ & 0 & $95 \cdot 1$ \\
\hline Amikacin & 34 & $44 \cdot 1$ & 55.9 & 0 & 0 & 100 \\
\hline Tobramycin & 41 & $85 \cdot 4$ & $14 \cdot 6$ & 0 & 0 & 100 \\
\hline Ciprofloxacin & 57 & $96 \cdot 5$ & $3 \cdot 3$ & 0 & 0 & 100 \\
\hline Totals & 248 & $75 \cdot 8$ & $22 \cdot 6$ & $1 \cdot 2$ & 0.4 & \\
\hline Essential correlation ${ }^{\star}(\%)$ & & & & & & $98 \cdot 4$ \\
\hline \multicolumn{7}{|l|}{ Cobas/MIC 2000} \\
\hline Piperacillin & 55 & $74 \cdot 5$ & 0 & $25 \cdot 5$ & 0 & $74 \cdot 5$ \\
\hline Imipenem & 57 & $86 \cdot 0$ & $8 \cdot 8$ & $5 \cdot 2$ & 0 & $94 \cdot 8$ \\
\hline Gentamicin & 57 & $89 \cdot 4$ & $8 \cdot 8$ & $1 \cdot 8$ & 0 & $98 \cdot 2$ \\
\hline Netilmicin & 57 & $87 \cdot 7$ & $5 \cdot 3$ & 3.5 & 3.5 & $93 \cdot 0$ \\
\hline Amikacin & 57 & $77 \cdot 2$ & $19 \cdot 3$ & $3 \cdot 5$ & 0 & $96 \cdot 5$ \\
\hline Ciprofloxacin & 57 & $78 \cdot \overline{9}$ & 3.5 & $17 \cdot 5$ & 0 & $82 \cdot 4$ \\
\hline Pefloxacin & 57 & $61 \cdot 4$ & $28 \cdot 0$ & $10 \cdot 6$ & 0 & $89 \cdot 4$ \\
\hline Totals & 397 & $79 \cdot 3$ & $10 \cdot 6$ & $9 \cdot 6$ & 0.5 & \\
\hline Essential correlation` $(\%)$ & & & & & & $89 \cdot 9$ \\
\hline
\end{tabular}

^See legend to table 4 


\section{Discussion}

Automated bacterial identification and susceptibility testing systems offer several advantages over conventional methods, one of which is the rapid provision of accurate information to the clinician. The Vitek system offers a rapid system (six to 10 hours) compared with the Cobas Micro and our MIC 2000 system (both 21 hours). The Cobas Micro system does offer the choice of a short incubation period (five hours), but should this short incubation period inadvertently be prolonged ( $>6$ hours) the rotor will be rejected, and it will not be accepted for further incubation in the event of a misidentification at five hours. The Vitek system is fully automated, whereas the Cobas Micro system has no incubation chamber, which makes a manual incubation step necessary. The rate of correct identification of Gram negative bacteria by the Vitek system in our study $(94 \%)$ is within the range of that obtained with comparable systems ${ }^{1278}$ and with the Vitek system ${ }^{910}$ in other studies. The Cobas Micro system offers an unacceptably low rate of correct identifications $(74 \%)$ at genus and species level. Remarkable misidentifications were 42 strains of $E$ coli (MIC 2000 and Vitek) which were identified as Shigella sonnei or Shigella sp by the Cobas Micro system.

To our knowledge, there are only two detailed studies ${ }^{36}$ and one abstract (O'Hara CM, Miller JM, Rhoden DL. Abstract presented at 91st Annual Meeting of the American Society for Microbiology, 1991) evaluating the Cobas Micro system in the identification of Gram negative bacteria. The identification rates obtained in these studies vary from $69-97 \%$, depending on the types of micro-organisms, the use of additional "external" reactions, and the incubation period used. In this study we found a large difference in the correct identification rate in the Cobas Micro system when strains were tested after several months of storage at $-20^{\circ} \mathrm{C}(86.8 \%$ at species level $)$ or immediately after isolation (65.4\% at species level). Adaptation to the culture media in the laboratory might explain this. No such differences were found in antibiotic susceptibility testing after storage.

The results for susceptibility testing of Gram negative isolates using the Vitek and the Cobas Micro systems compared favourably with our conventional system (97\% essential correlation for non-urinary strains and $95 \%$ and $91 \%$, respectively, for urinary strains), and with those from other studies. ${ }^{4-610}$ Non-urinary Pseudomonas strains scored somewhat lower in the Cobas Micro system ( $89.9 \%$ essential correlation). Both commercial systems showed many minor errors for the non-urinary strains with the penicillin group of antibiotics (Vitek: ampicillin $26.2 \%$ and piperacillin $10.9 \%$; Cobas Micro: ampicillin $21 \cdot 1 \%$, amoxicillin/ clavulanic acid $28.6 \%$ and piperacillin $11 \cdot 2 \%$ ) (table 5). Although the essential correlation for the system comparisons was high $(97 \%)$, complete agreement was only obtained in about $86 \%-89 \%$ due to these minor error discrepancies. Backes et al also found a high percentage of minor errors with ampicillin (26\%) when comparing the Vitek system with the MicroMedia systems. ${ }^{11} \mathrm{We}$ found many very major errors for urinary strains with nitrofurantoin in both systems, and with sulfamethoxazole and ampicillin in the Cobas system. Some of these errors were the result of unsuitable drug-organism combinations, which can give variable results in the laboratory (for example, Proteus-nitrofurantoin, Klebsiella/Enterobacter-ampicillin). ${ }^{11}{ }^{12}$ Fortunately these combinations are clinically unimportant.

The findings of this study suggest that the Vitek system is highly accurate in the identification and antibiotic susceptibility testing of clinically important Gram negative bacteria. The Cobas Micro system had many shortcomings in the identification of Gram negative bacteria, although the system was comparable with the Vitek system in determining antibiotic susceptibility. Both systems showed some weaknesses in the antibiotic sensitivity testing of Pseudomonas isolates. For the routine diagnostic microbiology laboratory, the Vitek system could offer a reliable replacement for conventional test systems.

The skilful technical assistance of Francien $J$ Van de Vondervoort-Gerritsma, Anita Kemper, and other technicians in the Department of Clinical Microbiology and Infection Control is greatly appreciated. We gratefully acknowledge the help of Robert Roosendaal.

1 Truant AL, Starr E, Nevel CA, Tsolakis M, Fiss EF. Comparison of AMS-Vitek, MicroScan and Autobac Series II for the identification of Gram negative bacilli. Diagn Microbiol Infect Dis 1989;12:211-15.

2 Freney J, Herve C, Desmonceaux M, Allard F, Boeufgras JM, Monget D, Fleurette J. Description and evaluation of the semiautomated 4-hour ATB 32E method for the identification of members of the family Enterobacteriaceae. F Clin Microbiol 1991;29:138-41.

3 Geiss HK, Geiss $M$. Evaluation of a new commercia system for the identification of Enterobacteriaceae and non-fermentative bacteria. Eur $\mathcal{F}$ Clin Microbiol Infect Dis 1992;11:610-16.

4 Hindler JA, Bruckner DA. Evaluation of the AutoMicrobic system for susceptibility testing of amino1987;25:546-50.

5 Washington JA, Knapp CC, Sanders CC. Accuracy of microdilution and the AutoMicrobic system in detection of $\beta$ lactam resistance in Gram negative bacterial of $\beta$ lactam resistance in Gram negative bacterial mutants with

6 Nemes P, Altwegg M. Rapid identification and susceptibility testing of routine urine isolates with the Cobas Micro semiautomated system. F Microbiol Methods 1992 16:181-94.

7 Pfaller MA, Sahm D, O'Hara C, et al. Comparison of the Autoscan-W/A rapid bacterial identification system and the Vitek Automicrobic system for identification of Gram negative bacilli. f Clin Microbiol 1991;29:1422-8.

8 Visser MR, Bogaards L, Rozenberg-Arska M, Verhoef J. Comparison of the Autoscan-W/A and Vitek Automicrobic systems for identification and susceptibility microbic systems for identification and susceptibility 11:979-84.

9 Stager CE, Davis JR. Automated systems for identification of microorganisms. Clin Microbiol Rev 1992;5:302-27.

10 oolfrey BF, Lally RT, Ederer MN, Quall CO Evaluation of the AutoMicrobic system for the identification and susceptibility testing of Gram negative bacilli. $\mathcal{f}$ Clin Microbiol 1984;20:1053-9.

11 Backes BA, Cavalieri SJ, Rudrik JT, Britt EM. Rapid antimicrobial susceptibility testing of Gram negative clinical isolates with the AutoMicrobic system. $\mathscr{f}$ Clin Microbiol 1984;19:744-7.

12 Sherris JC, Ryan KJ. Evaluation of automated and rapid methods. In: Tilton RC, ed. Rapid methods and automation in microbiology. Washington, DC: American Society of Microbiology 1981:1-5. 